\title{
The Russian Folk Religious Imagination: Web-based Digital Archive and Critical Edition
}

\author{
Jeanmarie Rouhier-Willoughby \\ University of Kentucky
}

The "folk" (Russian: narod) and intellectual conceptions of them play a profound, though misunderstood and underappreciated, role in Russian cultural history. The Russian concept of the folk has evolved over time, yet aspects of earlier, historical views persist to the present day.(1) In the Muscovy period, narod referred to all of the people in the state. When Peter I took power and began the Europeanization of Russia, the folk were identified as those who spoke Russian, not French, and maintained oral tradition. However, by the nineteenth century, Russian thinkers, like the German Romantics, idealized the folk, by then seen as simple peasants, arguing that the folk preserved the true essence of a nation's identity. Russian Slavophiles adopted this stance as well. The works of authors such as Gogol and Pushkin show that folk beliefs interacted with high culture in a profound way. This trend recurred in the twentieth century with the Derevenshchiki movement exemplified by Solzhenitsyn and Rasputin. During the Soviet period emphasis shifted from country to city and to the proletariat as the symbol for revolutionary Russia. As a result, a shift away from the folk occurred and the folk (and their practices) came to represent beliefs that the Soviet Union was trying to eliminate. Only after the mid-1930s did the concept of the folk as possible role models for the socialist state gain some currency. In the post-Soviet period we have seen a resurgence of the idealization of the folk as a symbol of the true Russia.(2) In essence, in order to understand Russia, one must study both the folk and elite conception of them and their belief systems. It is here that the intersection and also the disjunction between "high" and "low" culture is profound. Study of the relationship between folk and elite is hampered by the fact that, during the Soviet period, the official state policy of atheism discouraged work on religious texts. As a result, there is a wealth of unstudied material in all folk genres related to religion. While folklorists certainly collected material pertaining to religion throughout the Soviet period, they were often prevented from publishing their data. Such records languished in archives and private collections. Soviet theorists, working from nineteenth century positivist arguments, often contended that folk religion was based on dvoeverie ('dual faith'), meaning Christianity 
combined with an older, agrarian religion. The Soviet government, to perpetuate the official view that the folk never truly believed in Christianity, was willing to preserve folk tradition, but not its religious expression.

To study Russian religious belief without a consideration of folk conceptions is to overlook one of the most important sources of Russian religious ideas. Even during the Soviet period, folk religious beliefs played an important role in daily life. For example, people continued to perform those acts inherited from folk religion that insured the proper transition of the soul of the deceased to the afterlife. Typically, they held commemorative meals on the third, ninth, and fortieth days after death. Within the context of an officially atheistic society, this is striking, and it is only through an understanding of folk ritual and belief that we can explain why practices such as this existed in the Soviet context. The Russian Folk Religious Imagination (RFRI), funded by a National Endowment for the Humanities Digital Start-up Grant and by funds from the University of Kentucky, combines the skills of folklorists and linguists in an international collaborative project. Participants include: Jeanmarie Rouhier-Willoughby (University of Kentucky), Vera Kuznetsova (Institute of Philology, Novosibirsk), Yelena Minyonok (Institute of World Literature, Moscow), Mark Lauersdorf (University of Kentucky), Alexei Lavrentiev (Institute of Philology, Novosibirsk), Sergey Minyonok (Institute of World Literature, Moscow) and Doug Reside (University of Maryland). This research group unites specialists in prose narrative, ritual, and song, along with historical linguists, dialectologists, and computer programmers. Our goal is to explore folk religion in all its aspects, using a web-based format. Our focus is the language of the texts.

The Russian Folk Religious Imagination (RFRI) is a dual-language (Russian and English) multimedia critical edition designed to provide open access to audio, video, image, and textual materials. The centerpiece of the prototype site [www.rch.uky.edu/RFRI] is an audio recording of a Siberian variant of the legend about Christ's betrayal by Judas in Gethsemane. It is accompanied by a Russian transcript and English translation as well as by linguistic and folkloric commentaries (by Kuznetsova and Rouhier-Willoughby). In addition, we feature video of an Easter celebration from the Cossack region of Russia (with commentaries by Y. Minyonok and Rouhier-Willoughby) as well as folk icons of Christ. We have chosen to begin our work with Christ, the central figure of Christian faith, and legends and rituals related to his life. 
Focusing initially on Christ will allow us to foreground the most important holiday of the Orthodox faith, Easter, and its surrounding cycle. Had we chosen a saint, then the options for ritual study would be much less central to the belief system. During the next phase of our project we plan to prepare additional folk legends about Christ. After centering the foundational work of the project around the essential figure of Christian doctrine, we will expand to a larger conception of religion within the folk community and in the broader world of folk Orthodoxy (e.g., the role of Mary, the Saints, Old Testament figures, etc.).

Featuring texts related to one central figure allows us to demonstrate the range of existing variants. Examining variants is essential for studying the range of folk beliefs and the religious mind, since to base conclusions on a single text necessarily limits the scope of understanding of the issues. In addition to providing multiple variants, our website will allow scholars to easily ascertain the sources of the material in question, e.g., non-Christian Siberian myths or local pre-Christian beliefs. This will be done through direct, side-by-side searching and comparison of texts from different regions and time periods. Therefore, our project will ultimately incorporate a full range of variants for each text presented.

Ours is an interdisciplinary approach to the study of the Russian religious mind because it combines materials that are more often studied separately. Thus it features legends and religious songs, ritual practices, and icons. Each genre informs the other and contributes to a better grasp of the complex system of narratives, artifacts, and practices that constitute folk (and individual) belief.

\section{Legends and Religious Songs}

In Russian folklore scholarship, the legend is, roughly speaking, a prose genre that includes biblical figures. Sometimes these stories are retellings of biblical material, for example: how Judas betrayed Christ; how God created the world; how Adam and Eve were expelled from the Garden of Eden. In other cases, legends involve biblical personages, or other religious figures such as saints, in plots that are clearly apocryphal. Examples include Christ traveling Russia with Saint Peter or Saint Nicholas; the Mother of God visiting a Russian peasant, etc. One of the most exciting elements of our collection is a series of legends that were composed during the Soviet period or in the post-Soviet period about how Christ punished people who destroyed their churches at the behest of Soviet authorities. As a result, we can establish not only the dynamism of this genre, but also how it functioned throughout (Soviet) Russian 
history. Religious songs or verses are the poetic equivalent of this genre. As Selivanov [2004: 11,26] discusses in his history of the genre, these songs include pre-Christian elements as well as revisions of the Bible itself. An example is the song in which Saint Egor [George], not God, creates the world. Legends and religious songs are particularly interesting for several reasons. First, they reflect an intricate and fascinating combination of canonical religion with local beliefs, meaning Siberian native influences. Second, they illustrate folk conceptions of Christianity. For example, they explain why thirteen is an unlucky number: there were twelve apostles and Christ was the thirteenth and he was betrayed and killed. Another story explains that the aspen tree is cursed because Judas hung himself from that tree. Third, they show how legends incorporated a Soviet-era understanding of reality. For example, the legend on our project site makes use of contemporary Soviet social relations to explain the relationship between Christ and his apostles and Christ is called the "boss" [nachal'nik] of the Apostles. In addition, it explains the use of two common proverbial expressions relating to Judas that are based on a folk understanding of the events in the Bible. Fourth, they serve to illuminate the interaction among various folk genres. In the case of our first legend, we can trace certain formulaic expressions in the legend to a religious song about the Mother of God where she dreams of her son's fate. The teller clearly relied on the phraseology in this song to construct the prose narrative.

\section{Folk Iconography}

Folk icons are a distinct branch of Russian iconography. While churches were filled with icons painted by "officially sanctioned" artists, folk icons were produced by local painters for family homes and for some smaller churches. These icons reflect folk conceptions of Christianity. They portray Christ, for example, in the folk dress of the period. They depict events that are described in folk legends such as popular versions of saints' martyrdoms or miraculous events. Thus, while they are not canonical, they provide valuable insights into the local versions of Christian belief and what was relevant to the average person.

\section{Folk Religious Ritual Practices}

While ritual practices did not prompt the telling of legends, they are an essential component of folk religion. They provide valuable information on regional variants of belief and practice. They show how regional native traditions and pre-Christian Russian religion intermingled 
with canonical Christianity. Borrowed ritual acts were reinterpreted within the Christian system and became an integral part of the folk understanding of Christianity. For example, our project site provides video of various practices from the Cossack region of Russia related to Easter. An essential element in Cossack Easter celebrations, and indeed in celebrations across most of Russia, is a visit to the graveyard. The grave serves as the locus of the relationship between the ancestors and the living. For this reason, people clean and decorate graves as part of the Easter cycle and have a meal there, leaving some food behind for the dead. This practice is related to a pre-Christian ancestor cult, but has been reinterpreted within the Christian system. According to this interpretation, just as Christ died and rose from the dead at Easter, so too do the ancestors. Ancestors do not return to the earth, as Christ did (although that belief is expressed by some), but live another life in the afterworld. Such beliefs coalesce into a single system that provides a more complete picture of folk Christianity in Russia and illustrates its complexity.

\section{Commentaries}

All the material outlined above will be accompanied by commentaries provided by the collaborators and will include: references to related texts/rituals and their variants; discussion of the belief system surrounding the legend/ritual (e.g., why the aspen is a cursed tree); comments on the extent of dvoeverie (including borrowings from nonOrthodox religious systems); discussion of the relationship between folk material and canonical belief; description of the social functions of the texts/rituals; and discussion of how they reflect the teller's/participants' worldview. Initially, commentaries will focus on each individual text/ritual and the interrelations between them and other extant texts or documented rituals. As we amass more material, however, we will also provide thematic commentaries on particular issues such as dvoeverie or the image of Christ. Our materials will span the vast geographic area of Russia. We intend to examine the following questions:

1) Is "dual faith" an actual characteristic of Russian Orthodoxy? This issue has been hotly debated by scholars. Arguments have revolved around the official Soviet position on this issue and its subsequent influence on the approach to this material in the twentieth century.

There are questions about the extent and universality of dual belief and even its very existence. Levin [2004] has argued that what scholars of Orthodoxy call "dual faith" is present in all types of Christianity and has 
been erroneously considered to be something distinctly Russian. Our data will provide fodder for this debate by illustrating the extent to which non-Christian material forms a part of popular Orthodoxy and the role that it plays in the Orthodox context;

2) What are the various influences on the folk understanding of religion? Preliminary research shows many possible sources including: non-Christian Siberian mythic systems, pre-Christian Russian beliefs, non-Orthodox Christian beliefs, Soviet-era conceptions of daily life, and the folk tradition more broadly conceived. For example, some Siberian Orthodox Christians tell a legend about how God created the world that is clearly not Biblical, but borrowed from native Siberian religion. In this legend, Satan brings up dirt from the bottom of the ocean, which God (or Christ) uses to create the earth. The influence of local flora and fauna can be seen in a simple and elegant example of substitution in the biblical story of Noah and the flood. Here it is a teal and not a dove that brings back to the ark evidence that the flood has ended. Equally illustrative is the story of Adam and Eve, where the first man and woman fall from God's favor not because of an appetite for apples, but for berries.

3) What is the nature of folk Orthodoxy, how and where does it differ from canonical Orthodoxy, and how does it interact with formal institutions? While most "folk" believers did not doubt that they were Orthodox, their interpretations of religious doctrine could often differ from those of the mainstream church and, in fact, directly conflict with it. For example, it was traditional to have a sorcerer at nineteenth-century weddings to protect the couple, a practice to which priests strongly objected. Nevertheless, Orthodox peasants continued to invite them, despite the church's disapproval, and did not consider themselves "less" Christian as a result. This study will contribute to research on "lived Orthodoxy" and how heterogeneity of belief and historical change shape practice and faith over time.(3)

4) What functions did these legends serve within the group that produced them? The role of a given folk genre is an intricate and complex issue. Certainly, a major function of the legends was to transmit Orthodox belief and proper behavior. However, they also may serve to unite or divide the community, expressing issues that cannot be openly expressed in other types of discourse. An example would be a legend discussing how Christ determined women's role in society and its use to express dissatisfaction with the state of affairs in daily life.

5) How do the various aspects of folk Christianity interact? We consider a wide variety of genres and practices to examine their 
interactions and evolution, rather than as stand-alone expressions of folk belief.

6) What is the image and role of Christ in folk religious belief? While there are legends centered on a vast array of biblical and other religious figures, we have chosen to focus on Christ at this stage. We will address the issue of how folk conceptions of the central figure of Christianity interact with and deviate from Orthodox doctrine.

7) What are the range and extent of variation in these texts/practices over time? For example, we have access to multiple variants of legends about Christ punishing those who destroyed churches during the Soviet period. These clearly could not have existed in the nineteenth century. However, the motif of Christ doling out punishment was found in that period. We must examine whether and how these texts are related to one another, whether they existed in both European and Asian Russia, and whether they are based on established folk narrative patterns. Thus, changes in folk Orthodoxy as reflected in various ritual practices and narratives will form a core portion of our study.

Our long-term goals are to create a site that will allow comparison of a broad set of oral literature texts (songs/legends), folk iconography, and ritual descriptions in a single media-rich environment. This multimedia critical edition, combining these elements into a cohesive, integrated package, will be our first step in a new approach to folk material, one that brings together specialists in various fields to produce a sensory-rich analysis of folk religion as a coherent, integrated system. We will enable users to access and navigate the contents by creating coarse- and fine-grained linking between individual materials and pieces of those materials. The construction of this framework will rely on opensource tools to ensure maximum accessibility. There has been almost no work done in Slavic folklore that takes advantage of the digital technologies currently available. There are a reasonable number of scholarly websites devoted to the study of folklore in Russia and elsewhere.(4) Except for one project at the University of Alberta and a website to accompany Laura Olson's book Performing Russia,(5) there has been little development in the use of digital media to provide access to authentic materials for use by students and scholars.

As the materials are collected, we will digitize them, encode them using TEI-XML and annotate them with appropriate metadata. A key focus of technological development in the project will be experimentation with fine-grained linking not only between individual media elements, but also between internal segments of those elements. A 
simple example of this type of internal linking between media files is the bidirectional keying of an audio file to its accompanying textual transcription, such that the text "scrolls" to follow the progress of audio playback, and a given segment of audio can be activated from the corresponding location within the textual transcription. Similarly, an embedded folk reference in a legend text will be linked to its pictorial representation in a corresponding folk icon, locating, if necessary, a specific quadrant of the total image; in the reverse direction, activation of that same "hotspot" within the icon image will call up the specific portion of text in which it is referenced.

Current development work on our prototype infrastructure (as a template for the full-scale multimedia critical edition) has allowed us to address issues specific to the preparation of the media elements for their presentation in the way we envisioned. We have settled on using the Ajax XML Encoder (AXE), a multimedia annotation tool being developed at the University of Maryland, for much of the development of our project. AXE is a web-based tool for "tagging" text, image, audio and video files with XML metadata, a process that is now a necessary first step in the production of digital material. We plan to develop AXE to move beyond its current tagging functionality and to build in the linking functionality significant to our edition. AXE as it is being developed will enable the searching of tags across various multimedia, but we will need a system where the results of such searches are automatically activated. For example, when the user is watching a video of a ritual and arrives at a point where there is a tag that links to a tag in the commentary, or in an edited text, that link needs to "pop up" automatically giving the user the option to move from the video to the text.

The primary Russian texts collected for this digital edition will be encoded in XML and subjected to structural markup according to the most recent version (P5) of the internationally recognized Text Encoding Initiative (TEI).(6) Initial encoding would include a TEI Header (containing metadata about the text and its electronic version) and basic structural markup including textual divisions. The edition will also include markup describing many different aspects of the texts, and we will extend the TEI (adding elements and attributes) where necessary.

The scholarly apparatus of this project includes linguistic markup, enabling us to tag irregular forms and dialect features, and allowing us to identify features such as words borrowed from older Russian usage or Old Church Slavonic. We cite references and, when possible, links to 
other related texts, including both primary sources (Christian sermons, Biblical citations, other legend texts) and secondary sources (scholarly books and articles). We describe sources of borrowings from other cultures and contexts, usually localized aspects from native Siberian legends that are transferred into the Russian biblical legends (consider the aforementioned examples where a teal, not a dove, informs Noah that the floodwaters are receding). We also include identification and explanatory discussion of realia (that is, textual references to real-world people, places, and events) that appear in the legends. Finally, we will incorporate into our text encoding inter-media links between the legend texts and the ritual videos, folk iconography images, and song and legend audio files. The English translations of the primary Russian texts and all other textual elements of the project (commentary, analysis, transcription of audio and video text) will undergo similar TEI-XML markup.

A complete understanding of folk religion involves understanding the relationships among multiple aspects of traditional lore, many of which are most richly and accurately captured in image and sound. To truly understand the folk religious imagination, one must examine how various genres and practices interact. For this reason, the ideal scholarly product investigating folk religion would include not just materials collected together, but materials connected together. The technical preparation of the materials will allow for their use in research and teaching at any level, from the simple reading of texts and viewing of media, to detailed intertextual comparisons and thematic studies across genres and practices. The publication of the materials in an open-access on-line environment will allow for delivery of materials to a wider audience than could be reached by a scholarly print edition. Digital media give us the opportunity to make the rich results of this valuable research available to a wide audience for use in research and classroom teaching.

\section{NOTES}

1 See Olson 2003 and Kononenko 2007 for a discussion of Russian conceptions of the folk in the 20th and 21 st centuries.

2 See Rouhier-Willoughby 2008 for a discussion of the post-Soviet attitude toward folklore and folk identity among the urban populace.

3 See Freeze 1990, 1996, 1998, 2004; Worobec 2001; Chulos 2003; Kivelson and Greene 2003; Robson 2004; Smilianskaia 2003; and Shevzov 2004 for recent studies on lived Orthodoxy and the interaction of vernacular faith with doctrine and the church hierarchy. 
4 See: http://www.ruthenia.ru/folklore/publications.htm, http://www.ruthenia.ru/folklore/links.html, and http://www.crees.ku.edu/SEEFA/

5 See: http://www.arts.ualberta.ca/uvp/ and http://www.colorado.edu/germslav/Department/r-olson.htm

6 TEI P5: Guidelines for Electronic Text Encoding and Interchange, edited by C. M. Sperberg-McQueen and Lou Burnard, 2007 http://www.tei-c.org/release/doc/tei-p5-doc/html/

\section{BIBLIOGRAPHY}

Chulos, Chris. 2003. Converging Worlds: Religion and Community in Peasant Russia, 1861-1917. DeKalb: Northern Illinois University Press.

Freeze, Gregory L. 1990. "The Rechristianization of Russia: The Church and Popular Religion, 1750-1850." Studia Slavica Finlandensia 7: 101-136.

Freeze, Gregory L. 1996. "Subversive Piety: Religion and the Political Crisis in Late Imperial Russia." Journal of Modern History 68:2, 308-350.

Freeze, Gregory L. 1998 "Institutionalizing Piety: The Church and Popular Religion, 1750-1850," in Imperial Russia: New Histories for the Empire. Jane Burbank and David L. Ransel eds. Bloomington: Indiana University Press.

Freeze, Gregory L. 2004 "A Pious Folk? Religious Observance in Vladimir Diocese, 1900-1914," Jahrbücher für Geschichte Osteuropas 52(3): 323-340.

Kivelson, Valeria and Robert Greene, (eds.). 2003. Orthodox Russia: Belief and Practice under the Tsars. University Park: Pennsylvania State University Press.

Kononenko, Natalie. 2007. Slavic Folklore. Westport, CT: Greenwood.

Levin, Eve. 2004. Левин, Ив. Двоеверие и народная религия в истории России. [Dual Faith and Folk Religion in the History of Russia]. Москва: Индрик.

Olson, Laura. 2004. Performing Russia: Folk Revival and Russian Identity. New York: Routledge,

Robson, Roy. 2004. Solovki: The Story of Russia Told through Its Most Remarkable Islands. New Haven: Yale University Press.

Rouhier-Willoughby, Jeanmarie. 2008. Village Values: Negotiating Identity, Gender, and Resistance in Urban Russian Life-Cycle 
Rituals. Bloomington, IN: Slavica.

Selivanov, F. М. 2004. Селиванов, Ф. М. Народные духовные стихи. [Folk Religious Songs]. Москва: Русская книга.

Shevzov, Vera. 2004. Russian Orthodoxy on the Eve of Revolution. New York: Oxford University Press.

Smilianskaia, Elena B. 2003. Смилянская, Елена Б. Волшебники, богохульники, еретики: народная религиозность и «духовные преступления» в России XVIII в. [Sorcerers, Blasphemers and Heretics: Folk Religiosity and "Spiritual Crimes" in Russia of the $18^{\text {th }}$ century]. Москва: Индрик

Worobec, Christine. 2001. Possessed: Women, Witches, and Demons in Imperial Russia. DeKalb: Northern Illinois University Press. 